〔ミニレビュー〕

\title{
岡山県黒毛和種希少系統の保存について
}

\author{
米田一裕
}

(有) 米田遺伝了型研究所

\section{Conservation of a scarce population of Japanese Black cattle in Okayama}

\author{
Kazuhiro YONEDA
}

Yoneda Genotyping Laboratory Ltd.

\section{1. はじめに}

岡山県は古くから和牛の産地で「竹の谷蔓」由来の 黑毛和種系統牛が広く飼育されていた(羽部 1949)。し かし、現在は県外あるいは県内の他系統の需要が高 まったことでこの系統はごく少数になった。近年、黒 毛和種をはじめとする和牛は、肉用種として発展する 過程において肉質に重点を置いた改良を行うために能 力の優れた種雄牛が多用されている。そして、これら の子孫が繁殖集団として用いられていることから、肉 質の成績が優秀な個体は世代を超えて交配が集中する ことによって種雄牛や繁殖牛の系統が限定されてきて いる。和牛の繁殖集団の大きさは、海外の有力品種の
ような集団と比べても非常に小さいことから今後集団 全体の近交係数が上昇する可能性が考えられる。近交 係数の上昇は、近交退化現象や遺伝性疾患が発生する 可能性が高くなる。また、従来の繁殖集団において地 方固有の系統や特徴ある遺伝子が消失する現象が各地 で起こっており、和牛改良の基礎となった純粋系統の 存在が危惧されていることから希少系統の掘り起こし が叫ばれている。

一方、岡山県新見市には竹の谷蔓由来の希少系統を 絶やすことのないように他系統との交配を避けて保存 維持されてきた集団が残っている(図 1)。しかし、子 牛価格の低下、同系統種雄牛の途絶、飼養者の高齢化

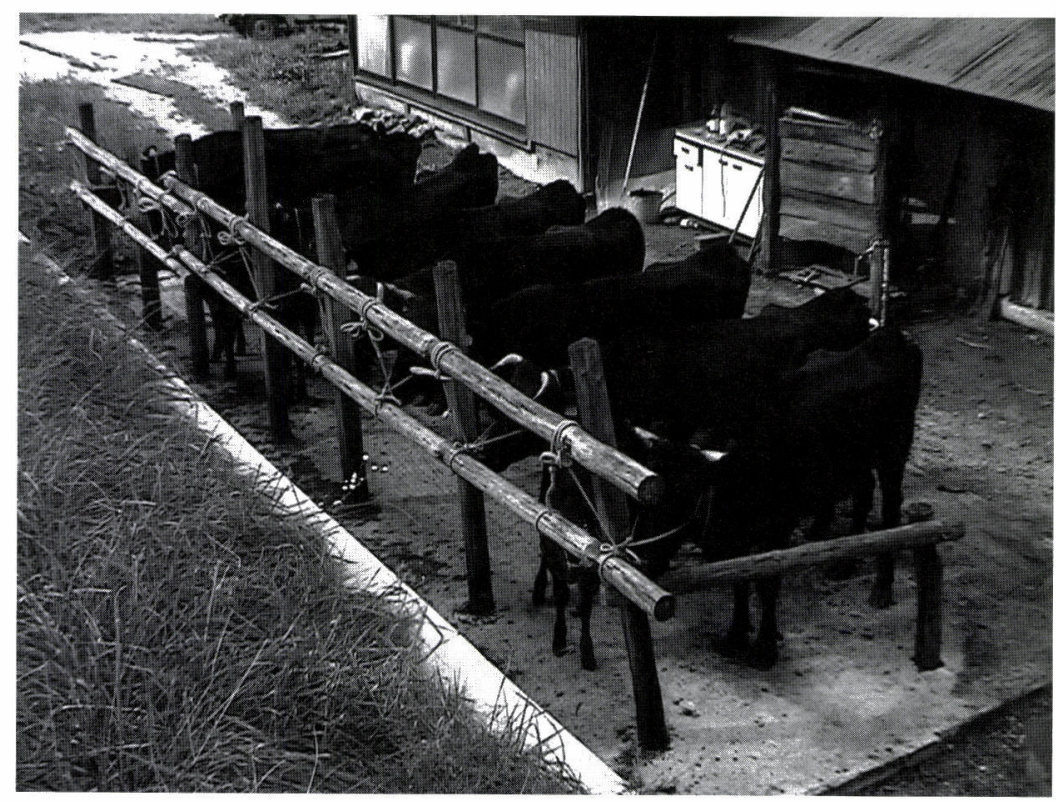

図 1. 阙川県の黒毛和種希少系統集団

連絡先: 米田一裕、有限会社 米田遺伝子型研究所

于 569-1017 大阪府高㭇市成合北の町 $774-2$

(e-mail: dradenoy@ybb.ne.jp) 
や後継者不足などにより世代を経るごとにその集団の 飼養頭数は減少してきている。この希少系統集団は、 どのような遺伝的特性を持っているかは不明であるこ とから分子遺伝学的に本集団の遺伝的多様性について 調査されている(米田 2007)。本稿では、岡山県の黑毛 和種系統集団の変遷を述べるとともに、本希少系統集 団の現状について述べてみたい。

\section{2. 竹の谷夢牛について}

古来より役用牛であった和牛は、中国地方の主要産 地で役用としての優良な形質を維持、改良、固定され てきた。江戸時代末期頃には、特に優良な系統を「蔓」 と称して珍重した。蔓という言葉は、植物の蔓に由来 するもので 1 本の蔓に同じ実が多数付くのと同様に、 牛の場合も特性のよく似た多数の優れた牛は血統を 辿ってみると同じ祖先につながっているという現象を 指している。蔓に属する個体を「蔓牛」といい、市場 に打いて一般の牛よりも常に高価に取引されていた。 岡山県阿哲郡新郷村 (現在の新見市)には、最古の蔓と して「竹の谷蔓」があった。江戸時代この地方は、た たら製鉄が盛んで大量の砂鉄と木炭が必要であったこ とから、これらの原料や製品を運搬する為に牛が必要 となり産地となったことが主な要因である。竹の谷曼 の成立は、導入した優良な雌牛が産んだ 2 頭の雌子牛 がいずれも優秀であったのをみて、次に生まれた雄子 牛を育成して母牛に交配するという近親交配を行い、 それらの産子が揃って優秀であったことからこの地域 の名より「竹の谷蔓」と呼ばれ、もてはやされたこと から始まったと言われている(井上 2003)。また、この 菖を維持する為に、自家産の雄牛 2 頭を育成して交互 に交配するという手法も伝えられている。蔓牛の造成 時に雄の使い方がはっきり出てくる例は少ないが、優 良牛の生産は、同一の祖先より同じような優良形質を 持つ個体同士の選択交配によって得られることを経験 的に知ることで、母子交配のような近親繁殖を頻繁に 行い、好ましい特性を遺伝的に固定し系統の造成に成 功した。これが蔓牛を造成する基本条件になっていっ たのではないかと考えられている。

優良な形質を集団全体に固定する方法は、近親交配 と厳格な選抜によって遺伝子の木モ型比率を高めるこ とである。これは現在の家畜育種学にあるべークウェ ルの育種法と同様、家畜の改良手段として最も合理的 な方法であることから西洋との文化交流のなかった当 時に扔いて、全く独立した形でわが国の先人たちが家 畜の改良を今日と同様に行っていたことは世界に誇る
べき業績であると羽部（1949）は述べている。

竹の谷蔓牛の特徵は、体格が一般より大きく(当時 の和牛雌の体高が $103 \sim 115 \mathrm{~cm}$ に対して竹の谷蔓牛は $121 \mathrm{~cm}$ 以上)、発育が良い、性質温順、乳量が多く、 連産に耐える繁殖力、長命で老衰の度合いが少ない等 の能力を非常によく遺伝する集団で現在の岡山系黒毛 和種の原形となっている。このような特徵は、県内及 び県外にも知れ渡ったことから多くの分かれ蔓ができ た。特に隣県の鳥取県日野郡や島根県仁多郡において も竹の谷蔓の分かれ蔓が繁栄した。

明治年代に入って全国の和牛の改良は、外国種であ るショートホーン種、デボン種、ブラウンスイス種、 ジャージー種、エアシャー種、ホルスタイン種などの 導入によって雑種を作ることと同義語となった。岡山 県に扔いても時流に従って外国種が導入されたが、和 牛助長の主張が強かったこともあり鳥取や兵庫などの 他地域と比べて導入数は少なく、竹の谷蔓牛を生産す る阿哲郡辺りでは雑種排斥の政策とったことから、そ の影響をほとんど受けなかった(松尾 1955、岡山県畜 産史編集委員会 1980)。

大正時代まで血統は雌によって継がれるものとさ れ、雄は単なる種取り用と認識されていたが、竹の谷 夢由来の雄が交配された産子成績が素晴らしく、その 子孫で種雄牛となるものが多く作られたことから竹の 谷菖由来の種雄牛による系統造成が始まった。

ここで岡山系黒毛和種の主な系統について少し説明 を加えておく。大正時代の後期に入り竹の谷蔓の流れ を汲む種雄牛として「第十三花山」が誕生し、非常に 優秀な子孫を残した。その子孫には「第四下前」「第 六清国」、「第六藤良」がおり、それぞれが始祖となる 系統が出来上がった。また、兵庫系黒毛和種の種雄牛 に「第十三花山」の子孫である岡山系黒毛和種が戻し 交配されたてできた種雄牛として「第三中屋」や「大茶」 があり、これらが始祖となる系統もあった((社) 全国 和牛登録協会 1982)。河本ら（1976）は、岡山県の黒毛 和種の高等登録を受けた雄抒よび雌の「第十三花山」 の遺伝的寄与率についてそれぞれ $11.33 \% 、 16.49 \%$ と 報告している。全祖先の中で特定の祖先が占める割合 を示す遺伝的寄与率は、大規模な淘汰や特定の個体の みの交配を続けない限り世代が進んでもあまり変化し ないことから現在の岡山系黒毛和種においても「第 十三花山」が高い值を維持していると考えられる。 昭和に入り和牛としての資質（皮虐、被毛、角、蹄など） の改良や時代の変遷に従って役用牛から肉用牛への改 良の為、兵庫系黑毛和種を数回導入することで系統間 
交配が実施され岡山系黒毛和種の各系統の改良がなさ れた。交通手段があまり発達していなかった当時、系 統は村や郡単位の狭い地域で閉鎖的に維持されてい た。よって、同じ系統でも地理的に飼養する場所が遠 くになってしまうと独自の交配圈ができることで、集 団の血縁関倸は遺伝的にも徐々に変化していったと考 えられる。

この間、わが国の和牛改良のための審査基準や血統 を明らかにする為の個体登録などの一元化により、昭 和 19 年に黒毛和種は品種として確立した。その後、 岡山系黒毛和種は、肉用牛としての改良目標に従って 雌牛系統に交配する種雄牛の系統が入り乱れて利用さ れることとなった。また、人工授精の普及における交 配圈の拡大により評判の良い種雄牛が集中して使われ たことから、現在、岡山県の黒毛和種は系統分離がさ れることなく混合された集団を形成することになって しまった。

\section{3. 希少系統集団の遺伝学的特性}

本稿で紹介する希少系統集団は、岡山県新見市に 残っている竹の谷蔓由来の系統である清国、下前、大 茶系に属しており、岡山をはじめ全国的に広まってい る藤良系との交配を行っていないことから岡山系黒毛 和種の中でも非常に珍しい集団である。本集団の家系 図は図 2 に示した。この家系は、1頭の雌を中心に同 系統の種雄牛を交配した後代に、数世代に分けて同系 統で別個体の種雄牛を導入している。その後、岡山県
において同系統の種雄牛作出は途絶えてしまったこと から、家系内から選抜した複数の種雄牛を交配するこ とで現在に至っている。破線は片親の詳細情報が得ら れていないものであるが、その祖先は同系統に属する ものである。

1 世代目の雌の血統は、竹の谷菖から分かれた寺田 菖由来である。特に母方の血統は 1864 年から続いて いることが阿哲畜産史（松尾 1955）にも記載されてい る。その血統には「第十三花山」が交配されており、 その後、清国系に属し、その家系からは「大茶」や「渡 辺」などといった有名な種雄牛を多く排出する育種集 団である。しかし、この雌牛は和牛登録協会の主導で 行われた優秀個体計画生産によって作成された個体で あり、父は兵庫系黒毛和種であった。よって、この雌 牛は純粋な岡山系の黒毛和種ではないが、その後の子 孫に交配した種雄牛は、すべて竹の谷蔓由来の岡山系 黑毛和種の集団である。

本集団の選抜基準は、主に外貌による審査を行って いる。特に竹の谷蔓の特徵となる皮膚、被毛、骨締り、 角色、角向き、蹄、体型などを受け継いでいる個体を 次世代に残しながら形質を維持してきた。このような ことから、現代まで脈々と竹の谷蔓由来でこの地域に 限定された黒毛和種が継承されてきたといえる。

本集団の遺伝学的特性として、米田 (2007) は、本集 団 30 個体と 11 座位のマイクロサテライトマーカーを 用いて本集団の遺伝的多様性について報告している。 その結果、観察された対立遺伝子数の平均值は 3.5 で

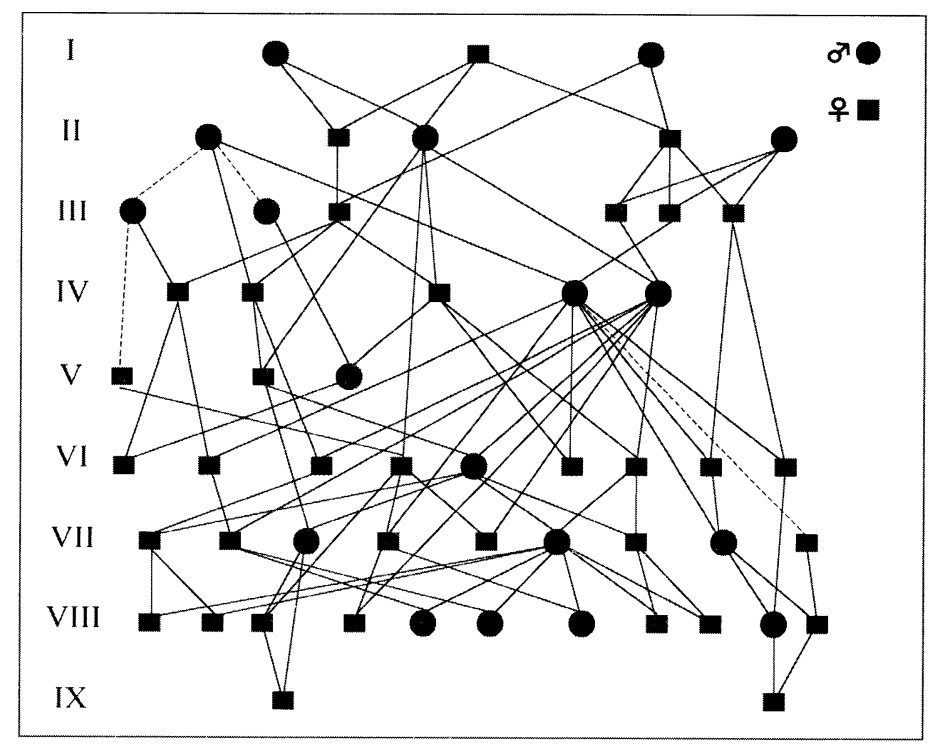

図 2. 希少系統集団の家系図 
あった。しかし、それぞれのマーカーの対立遺伝子頻 度に偏りが認められたことから、有効対立遺伝子数の 平均值は 2.1 であった。また、へテロ接合度の平均值は、 期待值と観察值に有意な差はなかった。さらに、本集 団の系統内の種雄牛を交配して生産された個体の世代 と家系内から選抜した種雄牛を交配して生産された個 体の世代に分けて近交係数とへテロ接合度について調 査してみたところ、同系統の種雄牛が交配に使用でき なくなり、家系内の種雄牛が交配に用いられるように なって近交係数は急激に上昇し、平均へテロ接合度は 減少することを認めている。

米田ら (2003) は、13 座位のウシマイクロサテライト マーカーを用いたウシ親子判定の結果より黒毛和種集 団とホルスタイン種集団の遺伝的多様性と親子判定の 有効性について報告している。特に黒毛和種集団は、 全国の様々な系統を含んでいることから出現対立遺伝 子数やへテロ接合度 (実測值)において遺伝的多様性を 確保していることが認められた。これは、わが国の和 牛の育種方法において、県や地域ごとに系統が成立し てきたことから系統間の遺伝的分化が起こっている可 能性を示唆している。

直接的な比較にはならないが、前述の本集団の調査 結果と黒毛和種集団全体のデータから同一のマーカー について出現対立遺伝子数とへテロ接合度を比較した ところ、本集団は全てのマーカーにおいて出現対立遺 伝子数、ヘテロ接合度ともに黒毛和種集団全体より低 い值を示した。

以上の結果から、本集団に打ける出現対立遺伝子数 の減少について、限定された個体数からの選抜過程で 遺伝子頻度の低い対立遺伝子は消失していることが示 唆された。本集団のへテロ接合度は、マーカーによっ て減少している值が異なっており、有效対立遺伝子数 が比較的多いマーカーはへテロ接合度が高かった。そ の理由として本集団の系統成立の過程において、基礎 繁殖集団が比較的大きかったことや資質改良の為に兵 庫県の黒毛和種の系統も導入されていたこともありへ テロ接合度が比較的高く保たれていたと考えられる。 また、本集団の交配方法として交配種雄牛を 1 頭に偏 ることがなく、複数個体を世代ごとに分けて使用して いたことからへテロ接合度の低下と対立遺伝子頻度の 偏りを防止していたと考えられる。しかしながら、有 効集団の大きさが減少するとともに同系統の種雄牛が 選抜されなくなり、家系内選抜の種雄牛が用いられる ようになって近交係数は、世代が進むごとに上昇して きたことから平均へテロ接合度の減少にも影響したと
考えられる。さらに、出現対立遺伝子数が減少してき ていることから遺伝的多様性は低下していることが明 らかとなった。したがって今後、本集団の遺伝子型の ホモ化が進む可能性が高いことが示唆された。

井上 (2003) は、これからの岡山和牛について肉牛生 産に打ける系統間交配のための素材として閉鎖集団に よる和牛の近交系の必要性を述べている。昭和 30 年頃、 兵庫県と広島県でそれぞれ新蔓造成事業として閉鎖型 の集団が作られ、特に兵庫県による蔓牛の生産は、現 在の兵庫系黒毛和種の完全な閉鎖系集団の形成につな がって㧍り、近交係数が平均 $10 \%$ を超えることから集 団全体が近交系となっていると報告している。した がって、本集団のように他の系統との交配を避けた閉 鎖集団は、系統間交配のための供給源になることが考 えられる。また、蔓牛由来の集団となればすでに遺伝 的特性は固定されていることから斉一性のある能力が 期待できると考えられる。

本集団は、蔓牛の時代からの特徴である大型の体型 や連産性などの形質が今も残っており近交退化現象や 遺伝病の弊害が見られないことから、できるだけ他系 統との交配を避けながら今後も集団を維持することが 望ましい。実用家畜において近交系が作られた例とし て前述の兵庫県と広島県でそれぞれ新蔓造成事業とし て閉鎖型の集団が作られたが、近交退化による繁殖成 績の低下は認められなかったといわれている (井上 2007)。また、イングランドのチリングハム牛は、野 生の状態で約 300 年間閉鎖的な小集団を維持しており 分子遺伝学的な調査の結果、25 のマイクロサテライト マーカーの内 24 マーカーはホモ型を示すほど均一化 していたが、集団の存続に問題がないようである (Visscher ら 2001)。これらの結果は、過去にたびたび 近親交配を経験した集団では、ボトルネックを受けた ことによって繁殖障害などの問題を起こすような遺伝 子が淘汰されていったのではないかと考えられる。し たがって、本集団においても近親交配を行っても障害 が起こらない可能性も示唆された。しかし、繁殖成績 の低下以外には、環境適応能力の低下や量的形質の性 能が低下する現象が知られていることから、極端な近 親交配は避けるべきであると考えられる。本集団の場 合、同系統の繁殖牛の飼養頭数が少ないことや同系統 の種雄牛が現在自家生産された同一家系の種雄牛し かいないことから、畜産センター等に保存されている 同系統の種雄牛の精液を利用することで、今後飼養頭 数を増やし、集団を維持していく必要があると考えら れる。 


\section{4. 今後の展望}

ウシは世代間隔が長く、各個体の経済的価值が高い ことからできるだけ早い段階で個体の遺伝的能力を把 握できれば選抜に要する経済的負担も軽くなる。近年、 家畜のゲノム解析に関する研究は著しく進展してお り、遺伝性疾患や生産形質に関わる遺伝子やその領域 が特定されてきている。特に単一遺伝子が原因となる ような遺伝性疾患については、遺伝子診断によりキャ リア個体を繁殖集団から排除することが可能となった (小邦 2002)。また、生産に関わる乳量、増体速度、脂 肪交雑などの量的形質においては、それをコントロー ルする多くの遺伝子座 (QTL) が同定されており、それ らの領域にある遺伝子型を遺伝子診断することで、そ れぞれの形質が優秀な個体を早急に選抜する (MAS)こ とができると考えられている。しかし、量的形質は多 数の QTL の遺伝子に支配されているので、一部の遺伝 子のみについて遺伝子診断による個体選抜をしてしま うと他の遺伝子座にある望ましい遺伝子を淘汰・消失 させてしまう危険性があるので容易ではない。すなわ ち、できるだけ多くの関連する遺伝子座を同定するこ とが望ましいが、同定されていない遺伝子座について は統計学的な手法を用いて総合的に評価しながら選抜 を進めることが必要となる。したがって、肉用牛を含 む家畜の改良には、さらに精度の高い統計遺伝学や分 子遺伝学的手法の利用が重要になる (長嶺 2006; 谷口 2006；佐々木 2007）。

本希少系統集団は、資質と称する外貌の選抜を中心 に行ってきたが、これらの資質形質と肉質形質との遺 伝的相関は無いことから肉質評価の指標とはならない (佐々木 2007)。したがって、肉質についての能力は未 定である。また、本集団の産肉能力について統計遺伝 学や分子遺伝学を用いて調查した報告は無く、遺伝性 疾患についても過去に発症したという報告や記録は無 いことから、今後本集団に扔いても生産形質に関する QTL の解析が必要になると考えられる。

今から 20 年以上前には岡山県に扔いても本集団の ような系統は多く存在して扮り、肉質、肉量共に優秀 な能力を持った藤良系の種雄牛を交配することで肉用 牛としての需要が非常に高まったことがあった。前述 の「第十三花山」の子孫である「第六藤良」の系統は、 他の系統より地理的に産地が遠くにあったことから独 自の交配圈ができたことで血縁関係は薄くなっていた と思われる。したがって、以前の岡山和牛は系統間交 配によるへテローシス効果があったと考えられる。系 統間交配は両者が遺伝的に離れている程、また各系統
の集団全体が遺伝的に斉一である程へテローシス効果 の可能性は高くなる。

本集団の個体は、その外貌を指標に選抜してきたこ とより体格が大型で骨締りも良く、また遺伝的にも齐 一化してきていることから肉量に打いては安定した生 産が可能と思われる。よって、肉質の良い種雄牛を交 配することでニーズにあった肉用牛の生産が期待で きる。

肉用種として改良されてきた黒毛和種は、海外の肉 用牛品種にはみられない独特の肉質を持っている。こ の特徵は、海外においても和食文化の交流によって知 られてきたことから、今後アジアをはじめ海外に向け て和牛肉の普及を考えていくことも視野に入れる必要 がある。しかし、その他の和牛品種や系統の改良目標 をすべて肉質に絞ったものにすることは、その他の優 良形質の消失につながる恐れがあることから今後の課 題としては、本集団を含め和牛の特徵となるような新 たな生産形質の QTL を見つけていくことが重要と考え られる。産肉能力では、枝肉形質以外にも肉の味や筋 纎維のせん断力など官能試験等によって評価されて いた形質や繁殖能力のような形質について、しっかり とした基準を設けて解析していく必要があると思わ れる。

現在、肉用牛のコマーシャル集団としての肥育牛や 繁殖牛において、優れた肉質や肉量をもった肉用牛を 生産する為には、系統間交配が有効な手段である。さ らに、繁殖技術の向上や各種の国家事業により全国的 にも同じような系統間交配から生まれた個体が大量に できるようになったことから、安定した肉生産を可能 としている。

一方、和牛改良において育種集団を維持する為には、 同一系統の種雄牛や繁殖雌牛が必要不可欠であり、世 間の流行に関係なく生産しなければならない。しかし、 収益性の高い人気のある系統ばかりが注目され、純粋 系統を維持する為の種雄牛や繁殖雌牛はますます少な くなってきている。かつて和牛生産地域であった中国 地方において、それぞれの系統を純粋に維持する為の 育種集団が減少してきている。2007年 10 月に行われ た第 9 回全国和牛能力共進会鳥取県大会では、各地の 希少系統を紹介するプログラムが初めて作られた。こ れらは現在に至る和牛の遺伝資源として今後の和牛集 団全体の遺伝的多様性の確保、肉用牛としての改良、 そして安定した肉生産などに重要な役割を果たす系統 集団であることを期待するものである。今後もこれら の系統集団をはじめとして純粋系統の造成を遂行して 
いかなければならない。そこで、血統情報が明らかで 純粋に系統維持されてきた本集団は、今後の系統造成 の遺伝資源として利用価値があると思われる。

本集団は、実用家畜の近交集団として学術的にも興 味媣く、今後、本集団を用いてマイクロサテライトマー カーやSNP 等の遺伝子型解析デー夕の蓄積によって、 家畜遺伝育種学的な問題となっている近交退化の主な 症状である繁殖力の活性や生存性に関わる遺伝子の解 明や系統間交配で現れるへテローシス効果の解明につ ながると考えられる。さらに優性効果やエピスタシス 効果の手がかりとなる量的形質遺伝子の機能解析への 利用の可能性がある。また、保全遺伝学の見地から絶 滅に瀕している野生動物や動物園動物の集団における 近交退化や遺伝的多様性の消失の問題に対して、近交 集団の遺伝子の動向をみることで小集団の遺伝的管理 の研究に利用できると考えられる。

\section{5. おわりに}

先人より受け継いだ和牛の遺伝子は、現在活躍して いる系統のみならず貴重な遺伝資源となる希少系統に ついても誇りを持って次世代に伝えるために保全して いくべきものと考える。

\section{謝辞}

本稿は、筆者が学生の頃より岡山和牛の系統やその 歴史について調査研究してきた中で、“いきた”家畜育 種を学ぶ教材となった希少系統集団について紹介し た。本集団を守ってきた和牛繁殖農家の方をはじめ、 関係者の方々に感謝するとともに、この機会を与えて くださった当誌編集委員の岡山大学国枝哲夫教授に深 甚なる感謝の意を表する。

\section{参考文献}

羽部義孝. 1949. 家音改良学とその応用. 産業図書.

井上 良. 2003. 岡山和牛復活への道. 岡山県阿哲郡神 郷町。

井上 良. 2007. 但馬牛.神戸ビーフと和牛の系統育種. （株）肉牛新報社。

河本泰生・山本幸造・猪 貴義. 1976. 岡山県におけ る黒毛和種高等登録牛の遺伝的分析 I. 遺伝的寄与 率と近交係数. 岡山大学農学部学術報告, 48 : $31-38$.

松尾惣太郎. 1955. 阿哲畜産史. 阿哲畜産農業協同組合 連合会. 新見.

長嶺慶隆. 2006. 家畜の QTL とポリジーン. 動物遺伝
育種研究, 34(2): 11-16.

岡山県畜産史編集委員会. 1980. 岡山県畜産史, 391-726. (社) 岡山県畜産会.

小邦朋子・佐藤敬明・竹田晴子・高見まり香・米田一裕·

森友靖生・杉本喜憲・国枝哲夫・松本道夫． 2002. 軟骨異形成矮小体躯症の遺伝子診断法の確立. 熊本 県農業研究センター畜産研究所平成 13 年度試験成 績書, 122-127.

佐々木義之. 2007. 和牛の選抜基準 外貌から遺伝子 へ. 動物遺伝育種研究, 35(1): 33-49.

(社) 全国和牛登録協会編．1982．和牛種雄牛系統的集 大成.（社）全国和牛登録協会. 京都.

谷口幸雄. 2006. ウシ脂肪交雑研究の今後：責任遺伝 子の同定から形成機構の解明へ, 動物遺伝育種研 究, 34(2): 53-61.

Visscher PM, Smith D, Hall SJG, Williams JA. 2001. A viable herd of genetically uniform cattle. Nature, 409: 303.

米田一裕・塗本雅信 - 石濱 賢 - 森田光夫. 2003. マ イクロサテライトマーカーを用いたウシの親子判 定. DNA 多型, 29-31.

米田一裕. 2007. 岡山系黑毛和種希少系統集団の遺伝 的多様性の評価. 日本畜産学会第 108 回大会講演 要旨, 37 . 